LOCAL WISDOM, 12 (2): 124-134, 2020
Local Wisdom Scientific Online Journal
ISSN: 2086-3764

\title{
Typology and Morphology of Traditional House of Sumbersari Village Udanawu Blitar District
}

\author{
Heru Hendri Iswanto1, Novi Sunu Sri Giriwati² and Respati Wikantiyoso ${ }^{3}$ \\ 1 Magister Architecture, University of Brawijaya, Malang, Indonesia \\ 2 Department of Architecture, University of Brawijaya Malang, Indonesia \\ 3 Department of Architecture, University of Merdeka Malang, Indonesia \\ Corresponding Author: heruhendri.hh@gmail.com
}

\begin{tabular}{ll}
\hline Keywords: & Abstract \\
typology, & Traditional houses in the village of Sumbersari are Javanese joglo \\
morphology, & houses that have been modified according to local culture. This \\
traditional house & Udanawu District, Blitar, the distribution is quite evenly distributed \\
& in Blitar Regency. This traditional residence has the characteristics of \\
& the limasan building roof and has a symmetrical facade building, this \\
& residence belongs to a Javanese family with a higher status, so it has \\
a uniqueness that is by the spatial layout and facade. Over time, only \\
changes in spatial layout and facade are related to human needs, \\
new technology, lifestyle, economic factors, inheritance, and cultural \\
rights. With existence, traditional houses that are increasingly \\
changing will eventually lose their identity. The purpose of this \\
study is to analyze typologies by classifying traditional dwellings \\
based on specific types and analyzing their morphology based on \\
the level of change and the application of the changes. The method \\
used is descriptive qualitative with a rationalistic discussion. The \\
results of the studio are the data in the form of tables about the \\
typology and morphology of traditional dwellings as the essence of \\
the instructions for the form of traditional dwellings that can be \\
contributed to the scientific architecture of the archipelago.
\end{tabular}

DOI: https://doi.org/10.26905/lw.v12i2.3839

Article History

$\begin{array}{lll}\text { Received } & \text { Dec 31, } 2019 \\ \text { Accepted } & : & \text { June 23, } 2020 \\ \text { Published } & : & \text { July 15, } 2020\end{array}$

@ 2017 The Authors. Published by GKAK UNMER Malang

\section{INTRODUCTION}

The majority of the people of Sumbersari Village are farmers, both as owners of rice fields and farm laborers, the people of Sumbersari Village highly uphold traditional Javanese architectural values including traditional building patterns. The building layout pattern is formed based on a trial and error system over a long period, therefore it is worth recognizing its meaning. (Dinata, Indira Rukmi, \& Antariksa, 2017) 
In addition to the traditions and customs that are still embedded today. The development of technology and various media has an impact on the increasing number of migrants who bring different architectural traditions and cultures. This is indicated to influence the erosion of traditions, customs, and culture that are characteristic of the community which will influence the shape of the arrangement of the house. So, it is necessary to study the characteristics of building facades for the preservation of ancient houses in Sumbersari Village, Blitar Regency.

In the middle of the modern era, the change in the shape of the house facade is influenced by the human mindset of the need for space. The change in the mindset of this community has resulted in changes in traditional houses in the village of Sumbersari, which will disappear from the original form of this traditional house. As the rapid flow of modern information into this village, according to(Pangarsa, 2009), since the 1980s the development of home architecture is very compliant to follow the architectural trends that follow the world of commerce and politics.

(Yu, 2009)said that modern houses emphasize the form and appearance of the game to show the social status of its inhabitants rather than the quality of the space inside. The result of this is the formation of spaces without concepts and the elimination of the phenomena that make up traditional houses in the village of Sumbersari.

The main problem is that if all traditional houses prioritize trends, then the characteristics of these traditional houses may disappear. According to Dakung in (Siti maria Ulfa, Antariksa, 2011)it is also possible that traditional architecture will become extinct amid society. But the uniqueness occurs in the traditional house facade in the village of Sumbersari, which is an adjustment in the condition of the home environment before making changes. Before the construction of his house in this village always associated culture and customs

This study aims to identify the characteristics of the building facade as forming the characters of the ancient houses of Sumbersari Village, Blitar Regency. From this research, it is expected to know the characteristics of building facade elements such as roofs, windows, doors, and ornaments. These characteristics are expected to be useful as input for the preservation of the ancient houses of Sumbersari Village, Blitar Regency.

\section{MATERIAL AND METHOD}

\section{Building Facade Review}

In the view of(Krier, 2001), the building facade conveys the state of culture when the building was built, the building facade reveals the criteria of order and arrangement, and is instrumental in providing possibilities and creativity in ornamentation and decoration. (Krier, 2001)confirms his opinion, the building facade in question addresses the building for the community. The face of the building is composed by dimensions, composition, and decoration. The facade is an architectural element that is able to voice the function and meaning of a building. facade components that need to be discussed gates and entrances, ground floor zones, doors, doors, walls, guardrails (fences) and roofs, while building facade compositions which include division, rhythm, ornaments, shapes, materials, colors and textures 


\section{Architectural Style and Facade of the Ancient House of Sumbersari Village}

The house in the physical sense, is where most of the domestic activities are carried out, including how to communicate the ideas or self-expression of residents who are culturally bound. Houses undergo changes due to increasing human knowledge from simple to more complex levels. This knowledge helps direct people to understand the values, conceptions, or understandings that guide actions in their efforts to find harmonious experiences to achieve calmness, tranquility, and equanimity. The view of the concept of security in residence gives a picture of the existence and status of a person, which allows him to have territorial control over his space. The house is only one tangible way to realize the effort to inhabit a place, which consists of physical building structures that contain symbolic, social and practical units (Sari \& Mutiari, 2014).

The house is one of the main human needs, so the planning of housing construction must be careful and consider many things. Some of them, namely physical potential and social cultural potential. Physical potential is a consideration of building materials, geological conditions and local climate. Whereas, socio-cultural potential consists of local architecture and way of life (Dinas Kimpraswil, 2002). consider climate factors. One type of modern house that appears is a simple house. Simple houses are the types of houses needed by the majority of Indonesian people, the majority of which are middle-to-lower. This house has limitations in the form of building area, land area, construction and building materials. Because of these limitations, simple houses are less able to handle climate problems properly, so the conditions inside the building are considered less comfortable and tend to be hotter. In addition, environmental factors that tend to be limited and dense also contribute to the conditions of such inconvenience, bearing in mind the conditions inside and outside the building affect each other (Soegijanto, 1999). Therefore, attention to the design of simple houses and their environment, or can also be called simple housing, is needed. The following are the characteristics of the facade elements in the architectural style of the ancient house of Sumbersari, Blitar Regency:

\section{Roof}

At first the types of Javanese building types were conveyed by (Ismunandar, 1997)and by (Prijotomo, 1995)were the types of tajug, joglo, pyramid, village and roasted. But in the development of archipelago architectural knowledge, with the permission of the manuscript as a source of exploration of knowledge, it is mentioned in the KaweruhKalang R. Sasrawiryatma script that, the types of buildings in Javanese architecture are: tajug, joglo, limasan, and kampong, this is also emphasized by(Prijotomo, 2006). And through a transformation process based on the analysis of the script KawruhKalang $R$. Sasrawiryatma(Susilo, Umniati, \& Pramono, 2014) the type of Javanese building is described as in Figure 1.

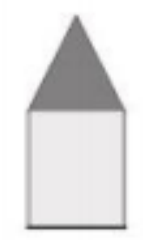

TAUUG

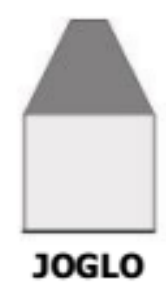

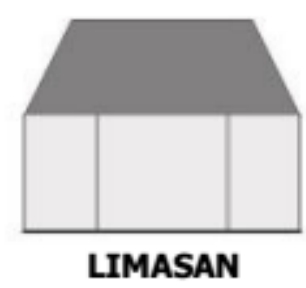

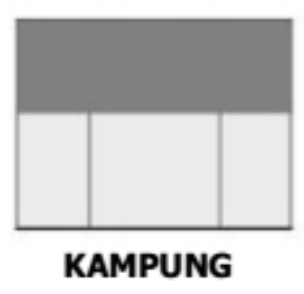

Figure 1. The type of Javanese building in the process of transforming the withdrawal in the elephant sector bycentering on its molo. source: (Susilo et al., 2014) 
The distribution of the limasanjoglo sector in each village to the traditional types of Javanese architecture

According to (Ismunandar, 1997)the type of theajajeng was devoted to the building of the mosque, but in the KawruhKalang R. Sasrawiryatma script it was not mentioned about the use of the type associated with the function of the building. Even each type of building can be used for any building function, but this is not uncommon. The use of tajug type, joglo type, pyramid type, and village type in buildings are always equipped with the addition of a pananggap roof, thus creating a sector that is divided into several sectors, such as Figure 2.

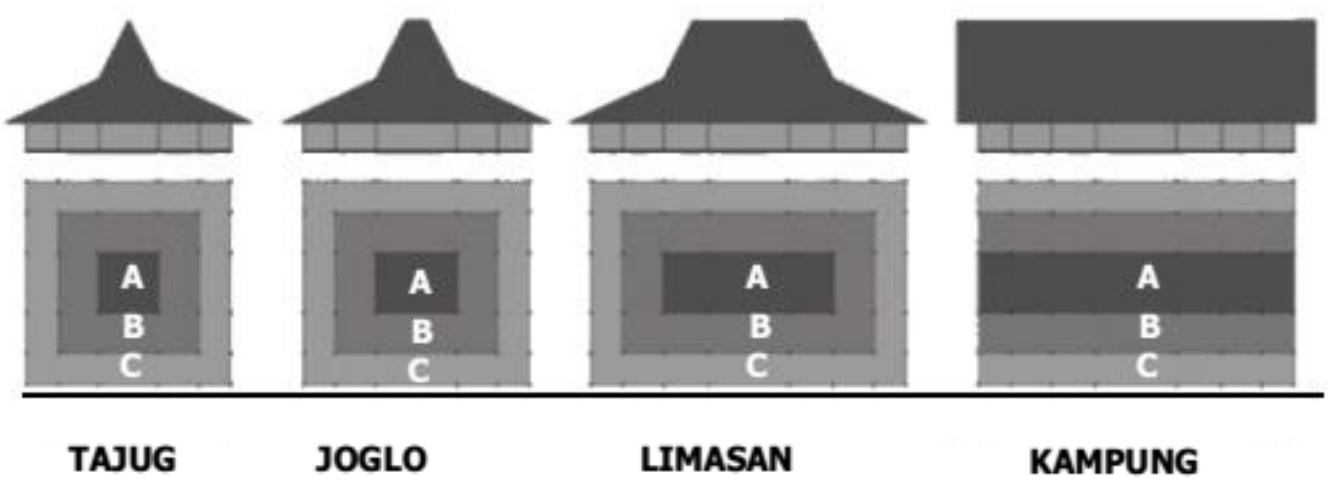

Figure 2. The distribution of the limasanjoglo in each village by type of traditional Javanese architecture source: (Susilo et al., 2014)

\section{The Role of Building Facades in Preservation of Buildings and Historical Histories}

Conservation and preservation efforts must be made in order to be able to adapt planning for the growth and sustainability of the evolutionary process of a historic environment. For this reason, it is necessary to prepare a rule that can control growth, so that continuity between the old building and the new one. This balance can be in accordance with observing the architectural elements that can significantly shape the character of a building and area. This can be taken into consideration as a reference for the development and growth of buildings and the environment in the future. The search for characteristics can be done through categorization with the principles of typology (Agustiananda, 2012).

\section{Method}

This study was conducted to examine the characteristics of the facade elements of ancient dwellings. The method used in this research is to use qualitative analysis methods. This qualitative analysis method is done by field observations and interviews. The research approach method chosen is using descriptive analysis conducted to explain how the condition of the object under study. Descriptive method of analysis is done by a historical approach. Descriptive analysis method that aims to describe how the characteristics of the object to be examined.

The scope of the study is limited by the criteria for determining which saples

a. It is an ancient residential building, a residential building that is 50 years or older (in accordance with Law R1 No. 11 of 2011).

b. The shape of the roof of the house is joglolimasan

c. The building has an original spatial layout even though the skin has changed 
$\mathrm{d}$. The building is still inhabited or occupied by the owner in order to obtain information or an overview of the ancient dwellings in the village of Sumbersari.

Determination of the sample is done by purposive sampling with the analysis is an old-fashioned house facade (in the form of building facade elements: roof, window, door and ornament), while its forming variables affect (Material / material, geometry, pattern / motif, location, geometry and color), as well as the elements of the building facade as a whole (according to the principle of composition: proportions, balance, repetition / rhythm, hierarchy). The selected sample is 8 pieces (Figure 3 )

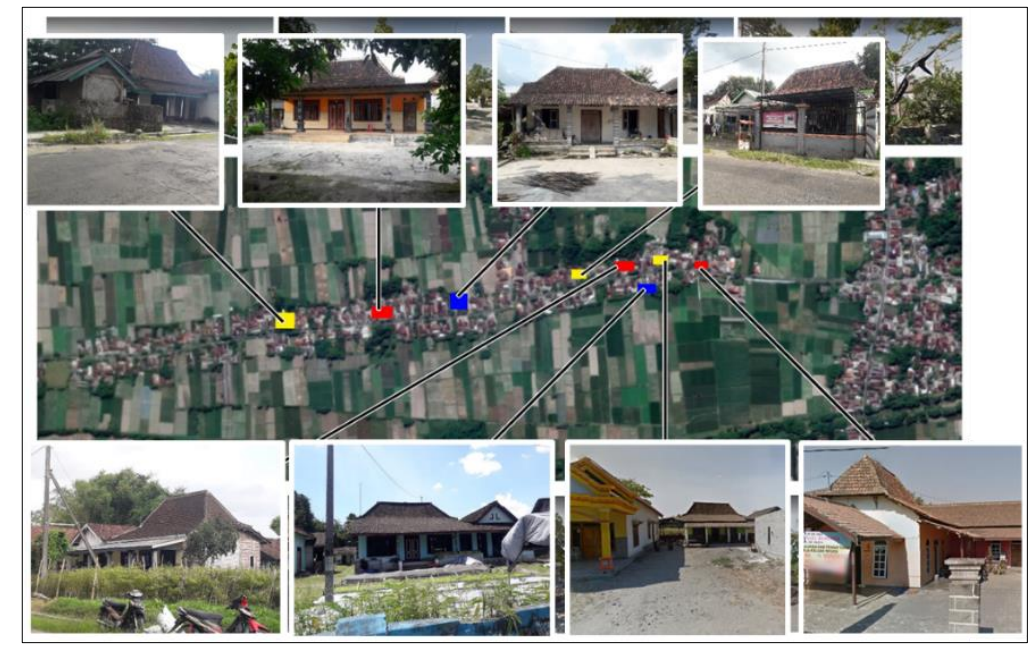

Figure 3. Distribution of Research Samples

\section{RESULTAND DISCUSSION}

\section{Physical Analysis of Buildings}

The building facade analysis which is carried out is based on the type of variable determined, namely the facade analysis as a whole and the facade forming elements. The building facade elements consist of 4 elements consisting of 3 elements namely the roof, windows and doors (each in terms of shape / geometry and material) and 1 element namely ornament in terms of geometry, material, motifs / patterns, location, and color.)

After observing there were 8 samples of ancient houses from 8 ancient houses. There are 3 types of spatial patterns in the direction of change.

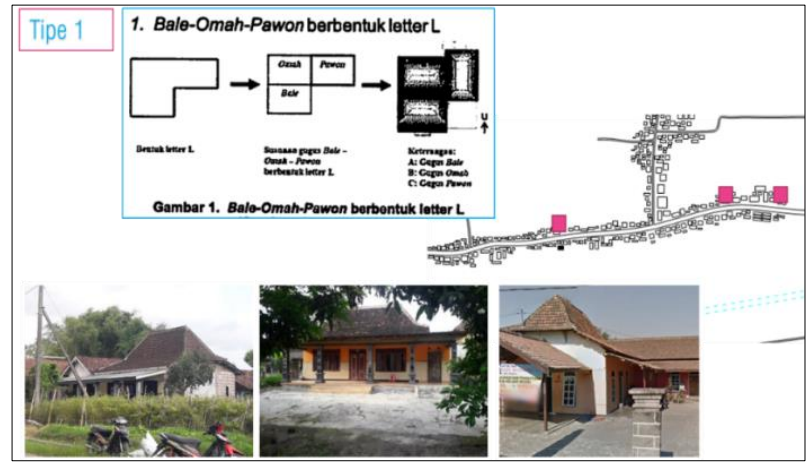

Figure 4.Types of Spatial pattern Direction of change 1 
After observing there were 8 samples of ancient houses from 8 ancient houses. There are 3 types of spatial patterns in the direction of change.

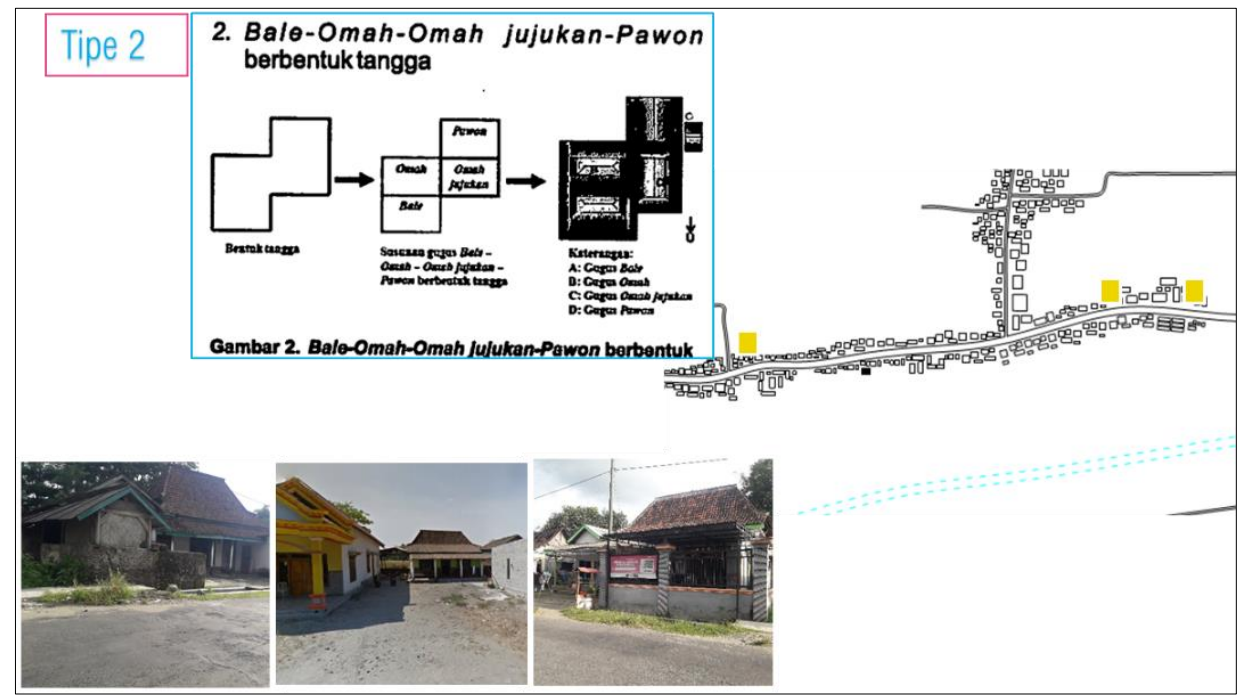

Figure 5.Types of Spatial pattern Direction of change 2

After observing there were 8 samples of ancient houses from 8 ancient houses. There are 2 types of spatial patterns in the direction of change.

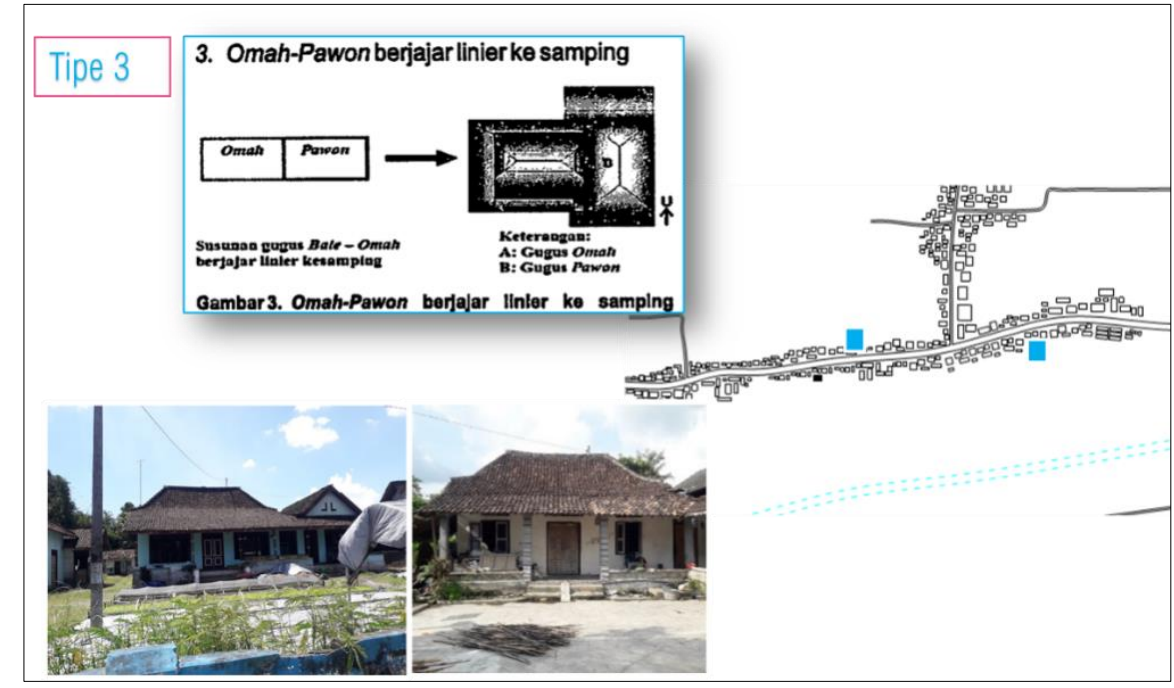

Figure 6. Types of Spatial pattern Direction of change 3

The following is a tabulation of the typology of facade components:

1. The door

Table 1. Typology of Door Facade Components

\begin{tabular}{lll} 
Component & Door Type & Material \\
\hline Door & Kuku Tarung & $\begin{array}{l}\text { All } 8 \text { houses use } \\
\text { panel doors }\end{array}$
\end{tabular}




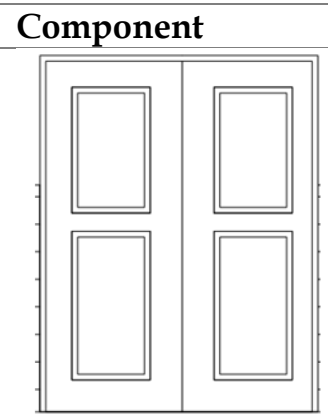

Door Type

Material

2. Window

Table 2. Typology of Window Facade Components

\begin{tabular}{lll}
\hline Component & Window Type & Material \\
\hline Window type 1 & Two openings & Wood paneling \\
& & with openings
\end{tabular}

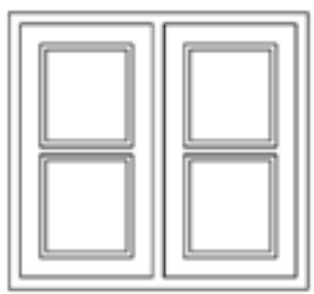

Without openings / dead Wooden sills with

Window type 2 glass glass windows

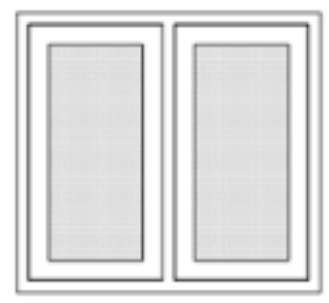

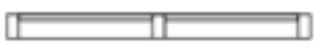

Window type 3
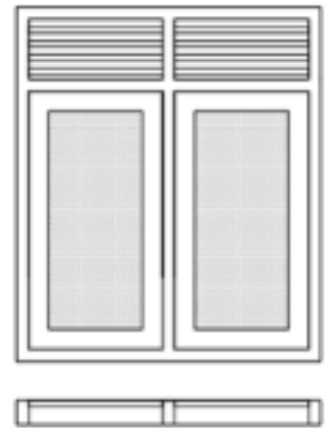

Without openings / dead Wooden frame glass

with dead glass windows added bovenlis above it

3. Walls

Table 3. Typology of Wall Facade Components

$\begin{array}{lll}\text { Component } & \text { Walls Type } & \text { Material } \\ \text { Walls type 1 } & \text { One brick wall } & \text { Pair of one brick } \\ & \text { pair } & \text { wall finishing } \\ & & \text { stucco and paint }\end{array}$


LOCAL WISDOM, Vol. 12 No. 2 July 2020

Local Wisdom Scientific Online Journal

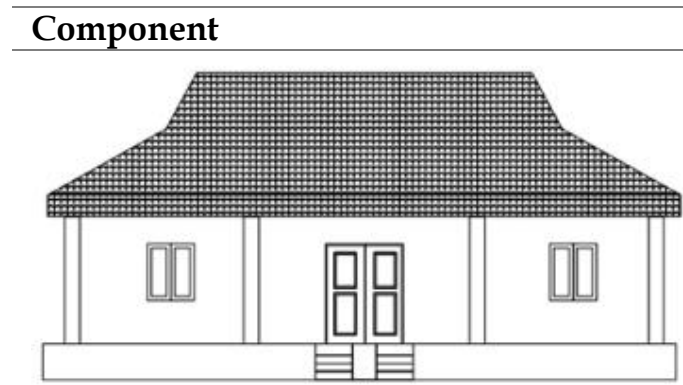

Walls type 2

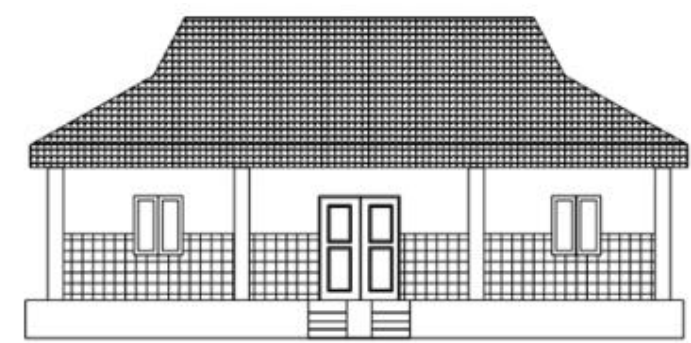

Walls Type

Material

Pair of one brick wall finishing One brick wall ceramic with a pair height of 1 meter above the floor

4. Roof

Table 4. Typology of Roof Facade Components

\begin{tabular}{lll} 
Component & Roor Type & Material \\
\hline Roof type 1 & Joglolimasan & All roof coverings use \\
roof type & tile
\end{tabular}

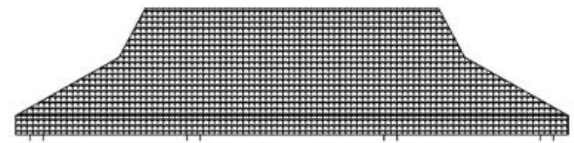

\section{Roof type 2}

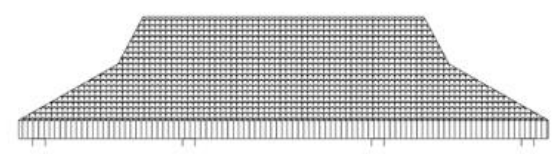

Joglolimasan roof type
Roof cover using tile part of the terrace using asbestos cover

5. Floor

Table 5. Typology of Floor Facade Components

Component Door Type

Floor

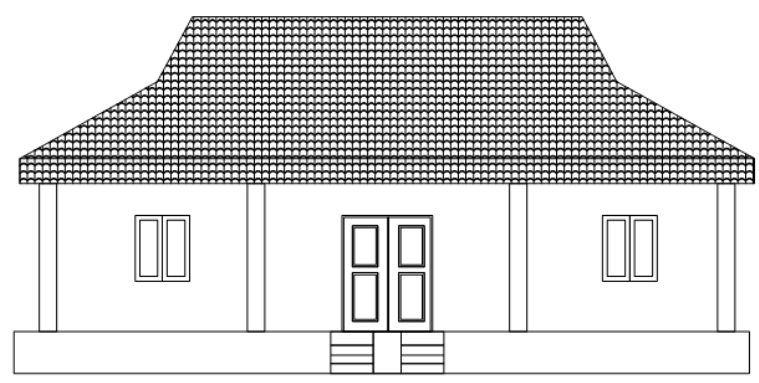

\section{Material}

The number of masses in this settlement has 8 buildings that have the same characteristics as the order of the entrance area, which is a large background building, all buildings are on stilts with another height of 1 meter, except for one building owned by the mother Kateni's family 
$\mathrm{m}$

For finishing floors there are 2 types: ceramic finishing and stucco finishing

While the building facade characteristics in terms of the principle of composition, are as follows:

\section{Proportion}

The outline proportion in the selected sample facade is the proportion of the distance of the pin element to the window on the left and right is the same.

- The proportion of wooden doors is in the middle of the area.

- The proportion of floors is the same around 0.7 meters -1 meter.

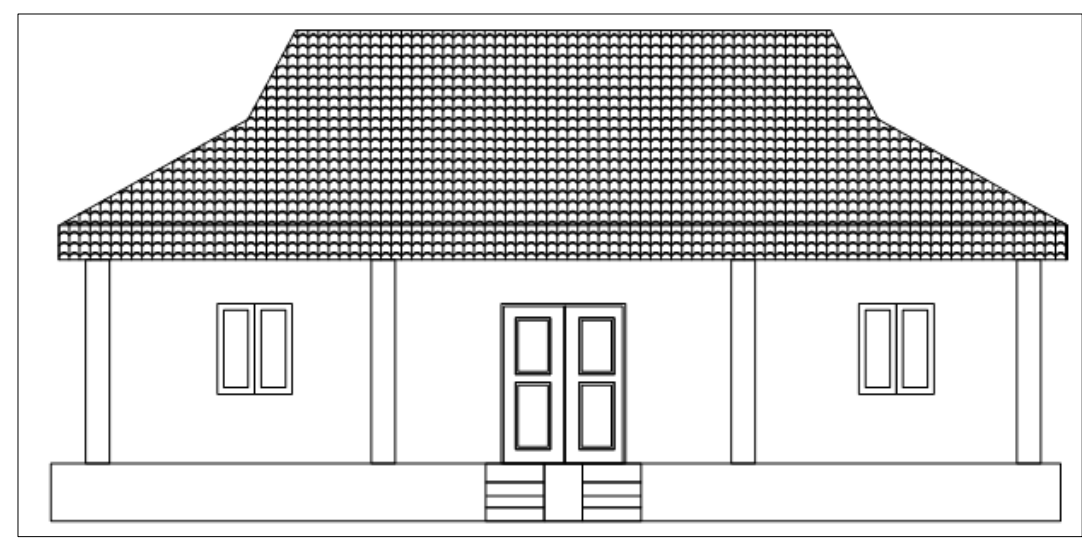

Figure 7. Building facade characteristics in terms of the principle of composition

2. Balance

Symmetrical, which is seen from achieving a balance between the right and left of the building.

3. Iteration / rhythm

There is a repetition of the shape of the opening element and the supporting column with parallel position, so that the shape of the position of the opening element represents the impression of a vertical and curved line in the facade, as well as the impression of a vertical line in the buffer column and there is a repetition of the shape of the ornamental element as in the list plank.

4. Hierarchy

In the overall composition of the hierarchy seen in the door element to the same type of window using different sizes.

3.2 Analysis of the Role of Building Facades on Preservation of Ancient Houses 
Analysis of the role of the facade on the preservation of the Ancient House was done after knowing how the characteristics of the facade elements in the selected sample. This analysis was conducted to strengthen the existing character in the Ancient House of Sumbersari Village, Blitar Regency, which includes the architectural style of the building contained in the building facade.

In the Ancient House of Sumbersari Village, Blitar Regency, there are relics of buildings and other types of buildings with architectural styles of ancient Joglo houses typical of Central Java. - Ancient dwellings that are formed give rise to characteristics unique to the Ancient Houses of Sumbersari Village, Blitar Regency. In identifying the style of the Ancient House of Sumbersari Village, Blitar Regency, one type of architectural style is found.

\section{CONCLUSION}

The Ancient House of Sumbersari Village, Blitar Regency has a strong characteristic of architectural nuances. However, most building owners do not realize the potential that can lift the visual image of the area. Some of the factors that influence the characteristics of this village are the architectural style of the building contained in the building facade in the village. In this village there have been several buildings that have changed, both in the facade elements and those that have changed into new buildings. The building facade design criteria in this village refer to the characteristics of the building facade elements and the architectural style of the building that exists in Sumbersari Village, Blitar Regency, which consists of the JogloLimasan roof architecture style.

\section{References}

Agustiananda, P. A. P. (2012). "Towards Urban Conservation in The City of Solo, Indonesia". Jurnal Sains ETeknologi Lingkungan, 4(2), 67-77. https://doi.org/10.20885/jstl.vol4.iss2.art1

Dinas Kimpraswil, (2002). Kepmenkimpraswil Nomor: 403/KPTS/M/2002 Tentang Pedoman Teknis Pembangunan Rumah Sederhana Sehat (Rs Sehat). 1999-2001.

Dinata, Y. H., Indira Rukmi, W., \& Antariksa. (2017). "Pola Tata Bangunandan Hubungan Kekerabatan Dusun Kasim, Kabupaten Blitar". Seminar Nasional Arsitektur Dan Tata Ruang (SAMARTA), (October), 1-8.

Ismunandar. (1997). "Joglo Arsitektur Rumah Tradisional Jawa". Semarang: Dahara Prize.

Krier, R. (2001). Architectural Composition London. Academy Edition, D-70736 St. Retrieved from http://www.axelmenges.de/buch/Krier, Architectural.pdf

Pangarsa, G. W. (2009). "Arsitektur Berbudaya Kemasan Nilai Hakiki Berlanggam Bahasa Negeri". Arsitektur Nusantarawacana, (arsitektur nusantara). Retrieved from http://arsitekturnusantarawacana.blogsport.com

Prijotomo, J. (1995). (1995). Petungan: Sistem Ukuran dalam Arsitektur Jawa. Gadjahmada University Press; Yogyakarta.

Prijotomo, J. (2006). Konstruksi Arsitektur Jawa. PT. Wastu Lanas Grafika; Surabaya.

Sari, F., \& Mutiari, D. (2014). "Perbandingan Rumah Tinggal Tradisional Jawa Dan Rumah Tinggal Modern Di Surakarta". Sinektika: Jurnal Arsitektur, 14(2), 217-224.

Siti Maria Ulfa, Antariksa, E. Y. T. (2011). "Pola Tata Ruang Dalam Rumah Tinggal Kuno Desa BakungKecamatan Udanawu Blitar". Soegijapranata, Universitas Katolik Indonesia, Ikatan Arsitek, 9. Retrieved from memer_dw@yahoo.co.id

Soegijanto, (1999). Bangunan di Indonesia dengan Iklim Tropis Lembab Ditinjau Dari aspek Fisika 
Typology and Morphology of Traditional House of Sumbersari Village Udanawu Blitar District Heru Hendri Iswanto, Novi Sunu Sri Giriwati and Respati Wikantiyoso

Bangunan. Direktorat Jenderal Pendidikan Tinggi Departemen Pendidikan Dan Kebudayaan.

Susilo, G. A., Umniati, S., \& Pramono, Y. S. (2014). "Model Proporsi Tipe Bangunan Arsitektur Tradisional Ponorogo". Temu Ilmiah Iplbi 2014, (1), 1-6.

Yu, S. (2009). "Trend Arsitektur". Rumah Yu Sing, 5 maret 20. Retrieved from http://rumahyusing.blogspot.com/2009/07/tren-arsitektur-2009.html 